\title{
Zinc Acetate
}

National Cancer Institute

\section{Source}

National Cancer Institute. Zinc Acetate. NCI Thesaurus. Code C47787.

A zinc salt of acetic acid essential for the synthesis of cholesterol, protein, and fats. Zinc plays an important role in the proper functioning of the immune system. Zinc is required for the enzyme activities necessary for cell division, cell growth, and wound healing as well as the release of vitamin A from the liver. It plays a role in the acuity of the senses of smell and taste and is required to maintain prostate reproductive health and insulin function. Zinc is also involved in the metabolism of carbohydrates. Zinc acetate is administered orally or parenterally as a nutritional supplement. 